\title{
Geochemistry of Lower Palaeogene bauxites - a unique signature for the tectonostratigraphic evolution of part of the Croatian Karst
}

\author{
Zoran Peh and Erli Kovačević Galović \\ Croatian Geological Survey, Sachsova 2, P.O. Box 268, HR-10000 Zagreb, Croatia; \\ (corresponding author: zpeh@hgi-cgs.hr)
}

doi: $10.4154 / g c .2016 .24$

\section{Article history:}

Manuscript received December 01, 2015 Revised manuscript accepted May 11, 2016 Available online June 28, 2016

Keywords: Bauxite geochemistry, Compositional Data, Discriminant function model, Forebulge unconformity, Adriatic-Dinaric Carbonate Platform, Croatia

\begin{abstract}
The origin and emplacement of Lower Paleogene Bauxites discussed here relies on recent perceptions concerning the development of the collision-induced diachronous discontinuity surfaces in certain parts of the Adriatic-Dinaric Carbonate Platform (ADCP), and in the Istrian Peninsula in particular. This process, related to forebulge uplift during the initial stages of the orogeny, is amply recorded in the geochemical signature of related Istrian Lower Paleogene bauxites (ILPB) as was shown in previous investigations. As their self-evident extension, due attention is paid here to the effects of a flexural bulge in another part of the platform with its own suite of Lower Paleogene bauxite deposits (LPB), notably in its Dinaridic unit. Explication of the typical patterns of bauxite formation is grounded in the development of discriminant function models based on the Compositional Data ( $\mathrm{CoDa}$ ) analysis of geochemical data. This method provides the solid ground for separation of the various a priori defined bauxite groups deposited in the different subaerially exposed platform palaeoenvironments. In the final analysis, the discriminant model characteristic for the westernmost compartment of the Adriatic SW Unit (Istrian Karst) is cross-compared with the analogous model of the entire ADCP taken from earlier investigation but reconsidered within the CoDa framework. It is done with the purpose of assessing the geochemical correspondence between the two event-markers (ILPB and LPB) and clarifying the nature of the pertinent tectonostratigraphic constraints. The computer models show that the forebulge unconformity is not a widespread phenomenon, being distinctly recognized only in the lstrian part of the ADCP.
\end{abstract}

\section{INTRODUCTION}

In spite of extensive bauxite research and mining activities in Croatia which provided abundant mineralogical and chemical archives, bauxite genesis, particularly in relation to the palaeokarst and its tectonostratigraphic constraints, has been underrated. Most certainly, this unfavourable situation can be ascribed to earlier prevailing perspectives on bauxites predominantly as an aluminum ore, with all research efforts concentrated on the assessment of conditions of their detection, exploitation and refinement. Occasionally, they were treated in the broader context of palaeoclimaterelated geochemical and mineralogical processes (e.g. ŠINKOVEC, 1973, ŠINKOVEC \& SAKAČ, 1982, 1991; SAKAČ \& ŠINKOVEC, 1991) and of local tectonics (BLAŠKOVIĆ et al., 1989). However, their tectonically induced origin was considered more seriously only after the models of orogenic evolution of the Adriatic (Adriatic/Dinaric) Carbonate Platform (ADCP) had been constructed with special reference to the External Dinarides of the NE Adriatic region, e.g. by VLAHOVIĆ et al., 2005; KORBAR, 2009; BRLEK et al., 2014. This approach, drawing also from ,recognition of forebulge related unconformities associated with early stages of foreland basin development" (CRAMPTON \& ALLEN, 1995), stressed the significance of a number of stratigraphic gaps occurring in the Mesozoic-Tertiary successions of the Croatian Dinarides. Considered from this perspective, the complex investigation of bauxites as ,tectonic and climatic event markers at regional unconformities" (D'ARGENIO \& MINDSZENTY, 1995) stimulated a search for a new lithostratigraphic scheme setting the background for regional correlation studies over the entire platform.
The most recent investigations of bauxites in Croatia had addressed the root causes of geochemical variations observed in the bauxite deposits of Lower Palaeogene age (LPB) from the Croatian karst (KOVAČEVIĆ GALOVIĆ et al., 2012) (Fig. 1), focusing especially on the Istrian Peninsula due to its specific geodynamic evolution through Cretaceous to Palaeogene times (PEH \& KOVAČEVIĆ GALOVIĆ, 2014). These studies attempted to explain regular variations in bauxite geochemistry both within regional (ADCP) and subregional (Istrian Peninsula) contexts highlighting changes of depositional and diagenetic characteristics during subaerial exposure of the platform. Although Istrian Lower Palaeogene bauxites (ILPB) accommodate the overall geochemical trend (marked primarily by the southeastward increase in chromium content), their stratigraphic position at the regional $\mathrm{K}-\mathrm{Pg}$ unconformity occurring in the Adriatic part of the platform (Adriatic domain, sensu KORBAR, 2009) must be treated with due caution because of the implicit possibility of a unique geochemical signature resulting from tectonostratigraphic constraints.

Essentially, the implied peculiarity of the ILPB revolves around the major hiatus between the Cretaceous and Palaeogene carbonate successions, which unlike the more south-eastern portions of the ADCP, lasted seemingly longer in Istria (e.g. VELIĆ et al., 1995; MATIČEC et al., 1996; TIŠLJAR et al., 1998; VLAHOVIĆ et al., 2005; OTONIČAR, 2007, 2008; KORBAR, 2009; CVETKO TEŠOVIĆ et al., 2011). As a result, the ILPB are underlain by carbonate rocks characterized by a wide age interval (from Albian to Santonian-Coniacian) suggesting the predominance of tectonic over eustatic controls due to differential 


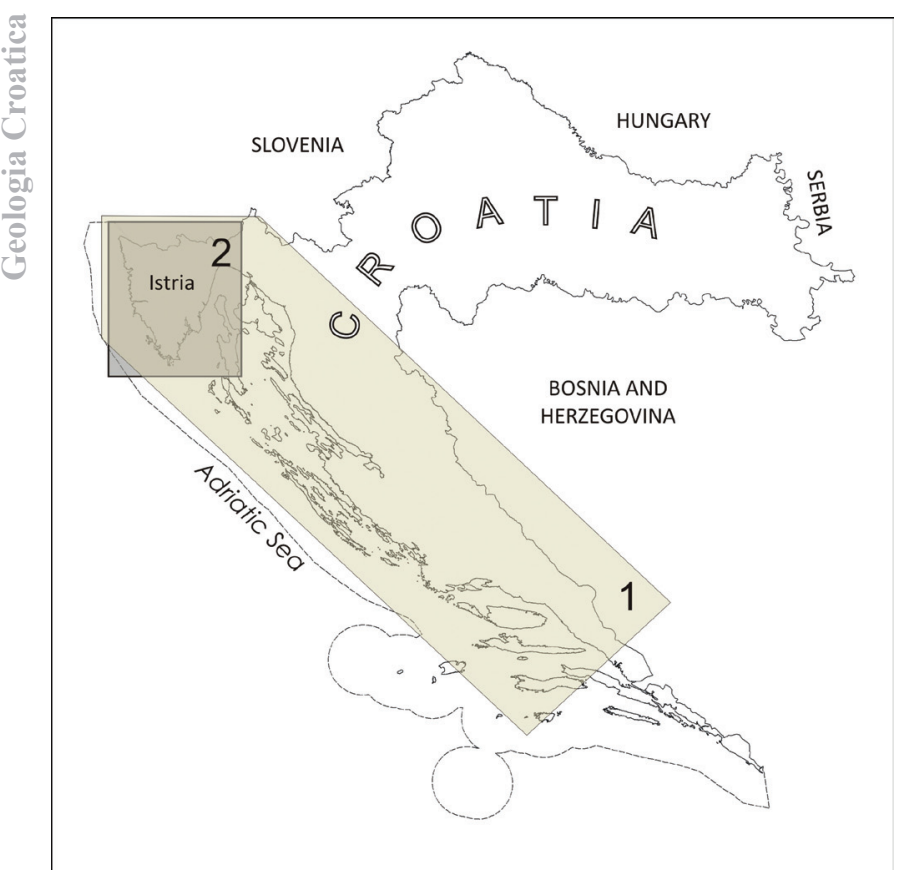

Figure 1. Topographic sketch map showing areas included in the two bauxiteresearch campaigns relevant for this study: 1 - Geochemical investigation of Lower Palaeogene bauxites (LPB) from the Croatian part of the Adriatic-Dinaric carbonate platform (ADCP) (KOVAČEVIĆ GALOVIĆ et al., 2012); 2 - Geochemical investigation of Lower Palaeogene bauxites from the Istrian Peninsula (ILPB) (PEH \& KOVAČEVIĆ GALOVIĆ, 2014).

erosion caused by uplift (MINDSZENTY et al., 1995), and also a prolonged period of terrestrial conditions necessary for the accumulation and diagenesis of the protobauxitic material. Presumably, the geochemical signal of the ILPB has responded to the coeval tectonostratigraphic constraints in a somewhat different way with respect to other LPB groups marked by different stratigraphic positions within the ADCP (Dinaric domain, sensu KORBAR, 2009; KOVAČEVIĆ GALOVIĆ et al., 2012). This premise infers a tacit antagonism between the ILPB and the other LPB groups, concerning their geotectonic setting - Adriatic vs. Dinaric domains of the ADCP - whereby the latter are associated with an unconformity formed during the supposedly shorter Late Cretaceous (Santonian-Early Campanian) to Palaeogene (EarlyMiddle Eocene) hiatus and, as a result, are underlain by carbonate bedrock of approximately the same age.

The idea underlying this study was to assess the analogy between the temporal sequences of the four ILPB groups (Adriatic) (PEH \& KOVAČEVIĆ GALOVIĆ, 2014) and the spatial emplacements of other, presumably single-sequence „non-Istrian” LPB groups (Dinaric) (KOVAČEVIĆ GALOVIĆ et al., 2012), based on their corresponding geochemical signatures. It is conceivable to elucidate the behaviour of the PB geochemical signal in different tectonostratigraphic settings, particularly with respect to development of a forebulge. This line of reasoning, in which time series (ILPB overlying a discontinuity surface at various stages of development) are substituted for spatially sampled data from a sufficiently large spatial domain (LPB from Istria to Dalmatia), is commonly termed ,ergodic" (implying space-for-time substitution). In pursuit of an ergodic solution, the integrated analysis of spatial and temporal domains generally requires comparison of appropriate models. For this purpose, a multivariate statistical assessment of a primary geochemical pattern distinguishing between the four groups of ILPB, (a priori separated according to bauxites overlying carbonate formations of different Cretaceous ages), was carried out using multiple discriminant analysis (MDA) as the most suitable mathematical technique. MDA is employed as a method of data reduction and organization providing an efficient means of geochemical partitioning between several bauxite groups defined by an independent criterion, in this case the stratigraphic formations, or lithostratigraphic units. The developed discriminant function model (DFM) is designed to account for the geochemical changes in time reflected in the ILPB due to the existent (presumably long-lived) subaerial exposure of the Istrian part of the Adriatic platform. The other model describing the variety of forms (bauxites) ,frozen” in a distinct timeframe related to the regional (apparently shorter) hiatus over a large proportion of a platform (Dinaric), is taken from earlier research (KOVAČEVIĆ GALOVIĆ et al., 2012) and redefined in the spirit of the $\mathrm{CoDa}$ analysis for comparison purposes. The aforementioned spatial-temporal correspondence (if present) is expected to be substantiated by analysis and reflected in the matching geochemical signal from both models.

Since the whole rock geochemical data analyzed here are of a compositional nature (represented in $\mathrm{wt} \%$ and $\mathrm{mg} / \mathrm{kg}$ ), providing information about relative magnitudes (as proportions of a whole), their statistical treatment is necessarily focused on the log-ratio approach introduced by AITCHISON $(1982 ; 1986)$ and disseminated by contemporary proponents of compositional data analysis (e.g., TOLOSANA-DELGADO et al., 2005; AITCHISON \& EGOZCUE; 2005; BUCCIANTI et al., 2006; REIMANN et al., 2012; BUCCIANTI, 2013).

\section{GEOLOGICAL SETTING}

The Croatian Dinaric Karst (NE Adriatic region) is an area of thick carbonate successions deposited from the Middle Permian to the Eocene on carbonate platforms of different ages, type and geotectonic settings. Some unresolved issues concerning its orogenic evolution in the later stages of development, particularly the relationship between the end-member palaeogeographic and geodynamic models is still subject to differing interpretations (VLAHOVIĆ et al., 2005, and references therein; KORBAR, 2009, and references therein). These models postulate the existence of a single (e.g. VLAHOVIĆ et al., 2005) as opposed to two carbonate platforms (e.g. KORBAR, 2009), usually with Adriatic-Dinaric designation (ADCP), developed as a result of fragmentation of the Adriatic microplate (Adria) during the Upper Triassic and the Lower Jurassic, and subsequent events at its plate boundaries (e.g. VLAHOVIĆ et al., 2005; SCHMID et al., 2008; KORBAR, 2009; SISCIANI \& CALAMITA, 2009; USTASZEWSKI et al., 2010 and references therein; MÁRTON, et al., 2010; ŠUMANOVAC, 2010; MÁRTON, et al., 2011; NOCQUET, 2012; HINSBERGEN et al., 2014). One of the themes highly relevant to the genesis of bauxites is associated with different tectonostratigraphic constraints characterizing the two contrasting platform domains, namely Dinaric and Adriatic, both with their pertinent tectonostratigraphic units, proposed in spite of the still uncertain NW extension of the Budva basin and time of opening of the NE Adriatic trough (KORBAR, 2009) (Fig. 2). The first refers to the recent External Dinarides, a highly deformed fold-and-thrust belt of Alpine origins formed by the collision of Adria with the Austroalpine and Tisia domains. The other is the Adriatic foreland, a more stable part of Adria characterized by normal faulting and gentle compressional late-orogenic deformations, which are tectonic features typical for Istria (MATIČEC, 1994; MATIČEC et al., 1996).

Although the dynamic interplay of synsedimentary tectonic activity and eustatic changes had continually modified the ADCP 


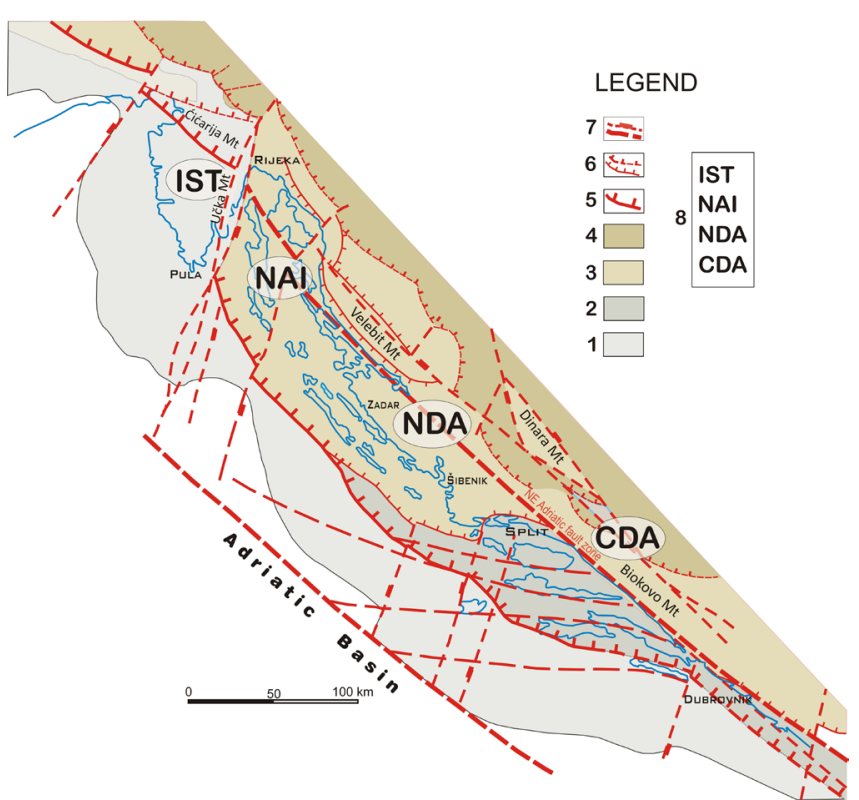

Figure 2. Simplified tectonic map of the Adriatic-Dinaric carbonate platform (ADCP), modified from KORBAR (2009): 1) ASWu (Istrian Karst); 2) ANEu (Dalmatian Karst); 3) DSWu (High Karst); 4) DNEu (Inner Karst); 5) Thrust front of the External Dinarides; 6) Thrusts of Adriatic and Dinaridic units; 7) Other major faults; 8) Investigated groups of Lower Palaeogene bauxites (LPB) from different quarters of the ADCP (after KOVAČEVIĆ GALOVIĆ et al., 2012): IST - Istria, NAI - NorthAdriatic islands, NDA - North Dalmatia, CDA - Central Dalmatia.

until the final uplift of the Karst Dinarides reaching its maximum extent during the Oligocene-Miocene period, from the perspective of bauxite formation only the period between the end of the

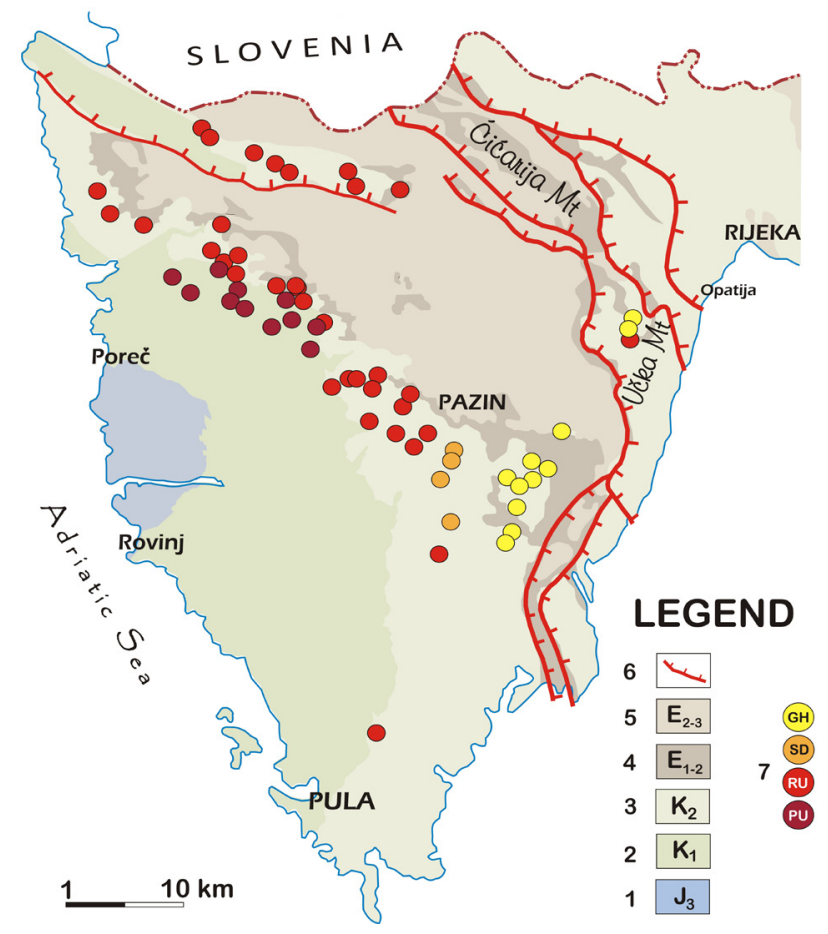

Figure 3. Simplified geological map of the Istrian Peninsula (compiled from the Geological map of the Republic of Croatia, 1:300,000, Croatian Geological Survey, 2009) showing locations of the sampled Istrian Lower Palaeogene bauxites (ILPB): 1) Upper Jurassic formations; 2) Lower Cretaceous formations (including PU); 3) Upper Cretaceous formations (RU-GH); 4) Palaeocene-Middle Eocene formations; 5) Middle Eocene-Upper Eocene formations (flysch); 6) Thrust faults; 7) Investigated Istrian Lower Palaeogene bauxites (ILPB) grouped in accordance to underlying Cretaceous formations (after PEH \& KOVAČEVIĆ GALOVIĆ, 2014).
Lower Cretaceous and the beginning of the Palaeogene is of interest for the scope of this investigation. This period is highlighted by a major discrepancy in the nature of a regional unconformity developed on the carbonate platform, marked by recognition of the strong forebulge effect in the Adriatic domain, Istria in particular, a feature only hinted at previously in the southeastern part of Dinaric High Karst.

As one of the five tectonostratigraphic units in the stratigraphic scheme of the entire ADCP, the Istrian Peninsula is recognized as the Adriatic SW unit (ASWu) or Istrian Karst (KORBAR, 2009) (Fig. 3), sometimes called stable Istria (e.g. MÁRTON et al., 2003; MÁRTON et al., 2010). Most of it is distinguished by a prolonged emersion phase at the Cretaceous-Palaeogene (K-Pg) boundary which caused a major hiatus between the two carbonate platform depositional systems - the Cretaceous passive margin shallow-marine carbonate sequence of the Adriatic Carbonate Platform and the Upper Cretaceous and/or Palaeogene shallow-marine sequences of the synorogenic carbonate platform, resulting from the specific evolution of the Adriatic foreland basin complex (ASWu). A major regional subaerial unconformity resulting from flexural deformation (uplifting forebulge) in front of the approaching Dinaric orogen is locally denoted by pronounced palaeokarstic features (DURN et al., 2003; OTONIČAR, 2007; KORBAR, 2009; BRLEK et al., 2013). These clues firmly support the idea that a large part of present day Istria probably formed land until the onset of the Palaeogene transgression (MATIČEC et al., 1996). However, no direct relationship with bauxite formation can be established in the area since the oldest bauxite-hosting rocks are represented by limestones of Albian age while the scattered outliers of the Eocene carbonate rocks overlie still older Lower Cretaceous formations (of Valangian to Barremian age), indicating erosional vacuity devoid of bauxites (PEH \& KOVAČEVIĆ GALOVIĆ, 2014). The complete stratigraphy of the ADCP carbonates from the Istrian Karst was described at length with reference to the typical Lower and Upper Cretaceous successions in VLAHOVIĆ (1999) as well as in GUŠIĆ \& JELASKA (1990) and CVETKO TEŠOVIĆ et al. (2001), respectively. Albian to Campanian lithostratigraphic units relevant to this investigation include the following in ascending chronostratigraphic succession: 1) Pula formation (PU - Albian), 2) Rušnjak formation (RU - Cenomanian), 3) Sveti Duh formation (SD - Upper Cenomanian-Lower Turonian) and 4) Gornji Humac formation (GH - Upper Turonian-Upper Santonian/Campanian) (MATIČEC et al., 2013). The latter three formations have been derived after the similar succession reported from the Island of Brač (GUŠIĆ \& JELASKA, 1990; STEUBER et al., 2005), with modifications.

In contrast to the Istrian Peninsula, the south-eastward portion of the Dinaric High Karst (Dinaridic SW unit, or DSWu, sensu KORBAR, 2009) is characterized by a Santonian (Early Campanian) to Late Palaeocene hiatus encompassing the Coniacian to Santonian interval (earlier determined as Turonian to „Lower Senonian”), narrowing considerably the approximate age interval of the associated bauxites. The absence of an obvious tectonically induced bulging effect (diachronous uplift), ruled out differential erosion that would have occurred during the subaerial exposure of the platform interior, introducing an entirely different kind of unconformity in this area. Accordingly, the $\mathrm{K}-\mathrm{Pg}$ boundary over the entire DSWu is marked by the underlying Cretaceous bedrocks having similar ages, such that the Upper Cretaceous strata underlying the bauxites generally shows bio- and lithofacies characteristics of the Gornji Humac $(\mathrm{GH})$ formation 
(KORBAR, 2009; KORBAR et al., 2012). This is strong evidence in support of a major discrepancy between the bauxite depositional environments concerning the two tectonostratigraphic units (ASWu vs. DSWu) in the Croatian karst. Although both are related to plate-interior settings (MINDSZENTY et al., 1995; D'ARGENO \& MINDSZENTY, 1995), they differ according to the longevity of the hiatus and consequences of the arching effect which is typical only for Istria.

\section{MATERIALS AND METHODS}

\subsection{Sampling, sample preparation and geochemical analysis}

Sampling was carried out on several occasions so that 50 LPB bauxite samples were collected from various sites all over the ADCP (including 21 early samples from Istria) (KOVAČEVIĆ GALOVIĆ et al., 2012) and 45 new Istrian samples added in a later campaign to complete the sampling scheme for the separate investigation of the ILPB (PEH \& KOVAČEVIĆ GALOVIĆ, 2014) (Fig. 1). Samples from all locations were collected in a random fashion following the idea that bauxites from a single regional unconformity ( $\mathrm{K}-\mathrm{Pg}$ transition) should represent a bulk geochemical composition regardless of their particular horizons within the ore body (e.g. at the contact with the related palaeokarst or immediate cover), particularly in the case of small deposits $\left(100-300 \mathrm{~m}^{2}\right)$ or occurrences typical for LPB in Croatia (Fig. 4). It is tacitly accepted in this work that multivariate analysis carried out on the bulk geochemistry of a number of cases is capable of identifying the most important geochemical processes by reducing all details along the vertical profile to a few mathematical functions.

Bauxite samples weighing about $3 \mathrm{~kg}$ in total were crushed by hand, split into fractions by quartering, and finally ground in a tungsten carbide pestle mortar mill (Retsch Lab Equipment) and sieved to $0.063 \mathrm{~mm}$ in preparation for the analytical work.

Chemical analysis was performed at the ACME Labs (ACME Analytical Laboratories Ltd.) in Vancouver, Canada, applying the Lithogeochemical Whole Rock Major and Trace Element analytical method. Total abundances of the major oxides and a few minor elements were reported on a $0.2 \mathrm{~g}$ sample analyzed by ICPemission spectrometry following a Lithium metaborate/tetraborate fusion and dilute nitric digestion. Total trace elements were analyzed by ICP mass spectrometry - refractory elements went through the same decomposition as the major elements (additional $0.2 \mathrm{~g}$ sample) while the rest were digested in hot Aqua Re-

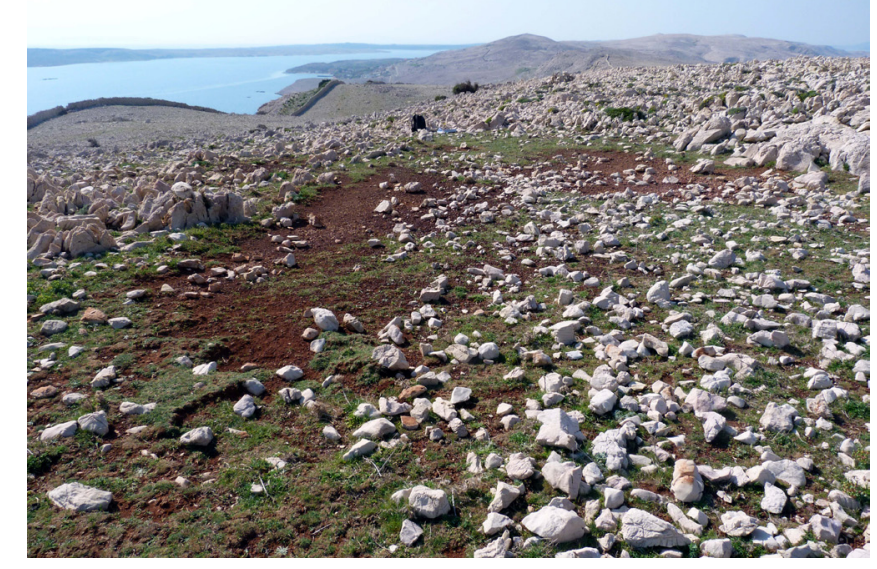

Figure 4. Outcrop of a small-scale Lower Palaeogene bauxite deposit (LPB) on Pag Island (Metajna-Zubovići) gia and analyzed by ICP MS ( $0.5 \mathrm{~g}$ sample). Analytical work was subjected to the strictest quality control in the ACME Labs, with blanks, duplicates and standard reference materials (STD SO-18) included in the CQ report, together with a certificate of analysis, as a measure of background noise, accuracy and precision. For the purpose of this work, the procedure for handling the data below the analytical detection limit (left-censored data) was accepted from TARVAINEN et al. (2005) as the substitution method of assigning one-half the detection limit value to censored data. This method is predominantly in use in geochemical and environmental studies (as per ANTWEILER \& TAYLOR, 2008) developed from earlier works on analytical chemistry (e.g., Analytical Methods Committee, 1987).

\subsection{Statistical considerations}

\subsubsection{Compositional data and log-ratio analysis}

Statistical analysis employed a selection of 32 elements including 10 major elements (represented as total abundances of major oxides) and 22 trace elements ( $\mathrm{Cr}$ represented as $\mathrm{Cr}_{2} \mathrm{O}_{3}$ ) performing as predictor variables in MDA. Data from earlier research work embracing LPB from all over the ADCP had to be recalculated into log ratios in order to be compatible with the recent discriminant function model (DFM) of Istrian bauxites. The strategy of analysis was adjusted to the objectives of this research so that ILPB data were installed as a foundation for the reference model against which LPB data were weighed (including identical procedures described in chapter 3.1). This arrangement meant that the tables in most cases combined the results of analysis of both data sets albeit separately and LPB is discussed later in the text (denoted as a, and b).

The analyzed dataset consists of 66 bauxite samples collected from ILPB deposits and occurrences, a priori separated into the four groups in accordance with rock formations (informal lithostratigraphic units from ASWu) as their immediate bedrock. The four groups include the Pula formation (PU), Rušnjak formation (RU), Sveti Duh formation (SD) and Gornji Humac formation $(\mathrm{GH})$ in upward succession. In contrast, the associated LPB database contains a total of 50 samples previously collected from different quarters of the ADCP (including Istria) and categorized in the four groups with a geographic designation: Istria (IST), North Adriatic Islands (NAI), North Dalmatia (NDA), and Central Dalmatia (CDA) (KOVAČEVIĆ GALOVIĆ et al., 2012); approximately in a NW-SW direction.

The summary statistics for the whole dataset prior to data transformation and subsequent multivariate statistical procedure are displayed in Table 1 (minimum, maximum, median, and geometric mean). However, this information is relevant only if one is interested in relative rather than absolute values such as, for example, in the case of comparison with other similar investigations, because the whole rock composition of bauxite samples represents the classical example of compositional data (CoDa) in geochemistry. Although the basic principles of CoDa are thoroughly explained in the previous work on bauxites (PEH \& KOVAČEVIĆ GALOVIĆ, 2014) it is deemed necessary to reiterate this issue again to some extent due to its relative novelty in the Croatian scientific literature, especially among geologists. The nature of CoDa implies a mathematical property that all variables (compositions) in the analyzed sample must sum to a unit value $(100 \%$ or 1.0$)$. As a result, all geochemical, mineralogical, and other datasets in the geoscience world are heavily plagued by the constant-sum constraint (CSC). This problem interferes with procedures of traditional statistics since individual variables 
Table 1. Descriptive statistics of raw (compositional) geochemical data for a) ILPB, and b) LPB datasets.

\begin{tabular}{|c|c|c|c|c|c|c|c|c|}
\hline \multicolumn{5}{|c|}{ a) ILPB } & \multicolumn{4}{|c|}{ b) LPB } \\
\hline Element & Min & Med & Max & g & Min & Med & Max & g \\
\hline $\mathrm{SiO}_{2}(\%)$ & 0.91 & 4.58 & 21.72 & 4.31 & 1.02 & 3.415 & 9.1 & 3.41 \\
\hline $\mathrm{Al}_{2} \mathrm{O}_{3}(\%)$ & 33.02 & 48.75 & 57.20 & 47.54 & 34.5 & 50.415 & 58.58 & 49.82 \\
\hline $\mathrm{Fe}_{2} \mathrm{O}_{3}(\%)$ & 4.13 & 24.58 & 42.21 & 25.02 & 14.76 & 25.955 & 45.96 & 25.62 \\
\hline $\mathrm{MgO}(\%)$ & 0.04 & 0.13 & 0.49 & 0.13 & 0.06 & 0.11 & 0.49 & 0.12 \\
\hline $\mathrm{CaO}(\%)$ & 0.03 & 0.08 & 7.80 & 0.10 & 0.04 & 0.115 & 0.64 & 0.10 \\
\hline $\mathrm{Na}_{2} \mathrm{O}(\%)$ & 0.005 & 0.01 & 0.33 & 0.01 & 0.005 & 0.01 & 0.33 & 0.01 \\
\hline $\mathrm{K}_{2} \mathrm{O}(\%)$ & 0.005 & 0.06 & 0.24 & 0.05 & 0.005 & 0.03 & 0.2 & 0.03 \\
\hline $\mathrm{TiO}_{2}(\%)$ & 1.30 & 2.90 & 3.67 & 2.76 & 1.6 & 2.955 & 3.88 & 2.84 \\
\hline $\mathrm{P}_{2} \mathrm{O}_{5}(\%)$ & 0.005 & 0.06 & 1.84 & 0.05 & 0.00 & 0.053 & 0.113 & 0.05 \\
\hline $\mathrm{MnO}(\%)$ & 0.005 & 0.05 & 0.12 & 0.05 & 0.02 & 0.05 & 0.46 & 0.06 \\
\hline $\mathrm{Cr}_{2} \mathrm{O}_{3}(\%)$ & 0.047 & 0.07 & 0.252 & 0.08 & 0.053 & 0.085 & 0.208 & 0.10 \\
\hline $\mathrm{Ni}(\mathrm{mg} / \mathrm{kg})$ & 52 & 200.00 & 524 & 186.31 & 88.0 & 224.5 & 1092.0 & 222.43 \\
\hline $\mathrm{Sc}(\mathrm{mg} / \mathrm{kg})$ & 30 & 47.50 & 123 & 47.43 & 35.0 & 54.0 & 91.0 & 56.07 \\
\hline $\mathrm{Ba}(\mathrm{mg} / \mathrm{kg})$ & 6 & 25.00 & 66 & 23.88 & 6.0 & 24.0 & 73.0 & 23.63 \\
\hline $\mathrm{Co}(\mathrm{mg} / \mathrm{kg})$ & 12 & 33.85 & 81 & 31.87 & 14.2 & 38.2 & 91.9 & 38.29 \\
\hline $\mathrm{Ga}(\mathrm{mg} / \mathrm{kg})$ & 25.3 & 49.85 & 66.4 & 48.54 & 33.6 & 53.55 & 65.1 & 52.49 \\
\hline $\mathrm{Nb}(\mathrm{mg} / \mathrm{kg})$ & 23.8 & 54.95 & 70.9 & 53.22 & 30.7 & 59.4 & 75.4 & 56.47 \\
\hline $\mathrm{Sr}(\mathrm{mg} / \mathrm{kg})$ & 27.6 & 96.95 & 992.7 & 96.56 & 27.6 & 74.7 & 220.4 & 74.59 \\
\hline Th $(\mathrm{mg} / \mathrm{kg})$ & 24.8 & 43.50 & 71.1 & 42.69 & 28.5 & 45.25 & 60.7 & 45.25 \\
\hline $\mathrm{U}(\mathrm{mg} / \mathrm{kg})$ & 4.6 & 10.60 & 29.4 & 11.05 & 4.6 & 8.7 & 26.9 & 8.58 \\
\hline $\mathrm{V}(\mathrm{mg} / \mathrm{kg})$ & 202 & 425.50 & 1341 & 444.38 & 286.0 & 539.0 & 1876.0 & 565.45 \\
\hline $\mathrm{Zr}(\mathrm{mg} / \mathrm{kg})$ & 246.6 & 517.20 & 667.9 & 497.95 & 312.3 & 532.55 & 721.2 & 523.30 \\
\hline $\mathrm{Y}(\mathrm{mg} / \mathrm{kg})$ & 31.4 & 64.65 & 111.0 & 61.44 & 31.4 & 69.7 & 255.9 & 77.00 \\
\hline $\mathrm{La}(\mathrm{mg} / \mathrm{kg})$ & 40.7 & 87.75 & 146.0 & 87.11 & 40.70 & 93.8 & 179.3 & 94.00 \\
\hline $\mathrm{Ce}(\mathrm{mg} / \mathrm{kg})$ & 64.6 & 178.35 & 1096.9 & 172.74 & 64.6 & 193.8 & 645.3 & 203.49 \\
\hline Mo $(\mathrm{mg} / \mathrm{kg})$ & 0.9 & 6.65 & 44.8 & 6.43 & 0.9 & 7.55 & 33.0 & 6.95 \\
\hline $\mathrm{Cu}(\mathrm{mg} / \mathrm{kg})$ & 14.5 & 95.35 & 247.6 & 87.75 & 21.9 & 82.3 & 250.5 & 87.40 \\
\hline $\mathrm{Pb}(\mathrm{mg} / \mathrm{kg})$ & 21.4 & 74.15 & 119.7 & 72.40 & 44.2 & 97.6 & 196.6 & 97.80 \\
\hline $\mathrm{Zn}(\mathrm{mg} / \mathrm{kg})$ & 10 & 74.00 & 633 & 78.65 & 12.0 & 90.0 & 422. & 93.01 \\
\hline As $(\mathrm{mg} / \mathrm{kg})$ & 0.25 & 51.15 & 269.60 & 45.18 & 1.7 & 36.15 & 154.9 & 28.57 \\
\hline $\mathrm{Cd}(\mathrm{mg} / \mathrm{kg})$ & 0.05 & 0.85 & 4.40 & 0.79 & 0.1 & 1.2 & 11.0 & 1.19 \\
\hline $\mathrm{Hg}(\mathrm{mg} / \mathrm{kg})$ & 0.03 & 0.29 & 2.23 & 0.29 & 0.03 & 0.225 & 1.02 & 0.22 \\
\hline
\end{tabular}

Note: Min = minimum; Med = median; Max = maximum; $g$ = geometric mean

are represented only as parts of some whole (or fractions of a constant sum) and, prevented from fluctuating independently (closed data), they are involved in spurious correlations. Formally, $\mathrm{CoDa}$ cannot be represented in their raw form as points in the open, Euclidean space, where the scale is absolute, not relative. They refer to a restricted sample space known as simplex (simplicial complex) consisting of $\mathrm{D}$ parts or compositions (e.g. geochemical variables). Thus a $\mathrm{D}$-part composition $\left(\mathrm{S}^{\mathrm{D}}\right)$ is really a subset of D-dimensional real space $\left(\mathrm{R}^{\mathrm{D}}\right)$ (PAWLOWSKY-GLAHN \& EGOZCUE, 2006) which can assume the Euclidean vector space structure only after the proper transformation of its components. From an array of transformations introduced in the literature, the centered log-ratio transformation (clr) of raw (compositional) data, originally proposed by AITCHISON (1986) is used here. The application of the centered log-ratio is deemed essential for processing $\mathrm{CoDa}$ in the multivariate statistical methods such as MDA since it preserves original distances between corresponding compositions allowing them to be handled in a straightforward way (EGOZCUE \& PAWLOWSKY-GLAHN, 2006; TOLOSANA-DELGADO, 2012). The singularity problem inherent to a clr-transformed covariance matrix could be circumvented if MDA operates on its reduced form, which is not relying on a full rank of covariance (DAUNIS-i-ESTADELA et al., 2011). Since clr-transformed data represent unbounded real vectors in real space, in this case Mahalanobis distances (MD) stay invariant regardless of which component may be removed from the analysis (BARCELÓ-VIDAL \& PAWLOWSKY-GLAHN, 1999). Nonessential clr-transformed variables may be amalgamated (,other”) and removed from further analysis.

Clr-coefficients are computed from the following expression:

$\operatorname{clr}(x)=\left(\log \frac{x_{1}}{g(x)}, \log \frac{x_{2}}{g(x)}, \log \frac{x_{3}}{g(x)}, \ldots, \log \frac{x_{D}}{g(x)}\right)$ :

where $x_{1}, x_{2}, x_{3}, \ldots x_{D}$ represent parts (compositions), and $g(x)$ represents the geometric mean of the parts.

As the compositional nature of geochemical data is expressed either in $\mathrm{wt} \%$, or in $\mathrm{mg} / \mathrm{kg}$, affecting the scale, all measurements are converted into $\mathrm{mg} / \mathrm{kg}$ before transformation by multiplying $w t \%$ by $10^{4}$.

\subsubsection{Building a predictive discriminant model (DFM)}

Multiple discrimination analysis (MDA) is one of the most exploited traditional multivariate statistical techniques particularly effective in building the predictive models of a multi-group discrimination established on the array of independent, or predictor variables. This method is amply described in earlier papers with similar targets and subjects of investigations (e.g. PEH \& HALAMIĆ, 2010; PEH \& KOVAČEVIĆ GALOVIĆ; 2014; GALOVIĆ \& PEH, 2016) and will not be thoroughly discussed 
here. This also relates to the process of model building - from the structural to the functional, by assigning the geological meaning to discriminant functions (labeling) - which is the stepping stone of each MDA. It suffices to say that here, the scope of this study is focused on building the two predictive discriminant models with maximum classification efficiency, based on the two sets of bauxite groups defined earlier as: a) ILPB (containing PU, RU, SD and GH groups) and b) LPB (containing IST, NAI, NDA and CDA groups); and the 32 log-ratio transformed CoDa chemical variables (whole rock chemical analysis). The latter set (b) includes the log ratio adjusted LPB model already defined in the earlier project (KOVAČEVIĆ GALOVIĆ et al., 2012) and added to this investigation for comparison purposes and discussion on tectonostratigraphic constraints with possible ergodic implications. To this end, a discriminant analysis from the statistical software package of STATISTICA, Release 7.1 (Statsoft, Inc., 2006) was used in order to achieve the best separation between the groups.

\section{RESULTS AND DISCUSSION}

Results of the MDA are briefly recapitulated in Table 2. containing: a) the multivariate test for the overall significance of discrimination and; $b$ ) the tests of residual roots (discriminant functions). The Wilks' 1 statistical test, employed routinely in the analysis, shows the vanishingly low probability $(\mathrm{p}<0.000)$ confirming that all bauxite groups have the same multivariate mean, which is compulsory in order to safely proceed with computing discriminant functions (DFs). Since the number of groups in the studied cases is only four $(\mathrm{K}=4)$ the between-group variation is completely explained by the three discriminant functions (K-1). However, examination of Table 2. reveals that only the first two discriminate functions justify closer inspection. DF1 and DF2 together account for more than $94 \%$ and almost $93 \%$ of the total between-group difference in ILPB and LPB models, respectively,

Table 2. Multivariate test for overall significance of discrimination, and tests of residual roots for a) ILPB discriminant function model, and b) LPB discriminant function model.

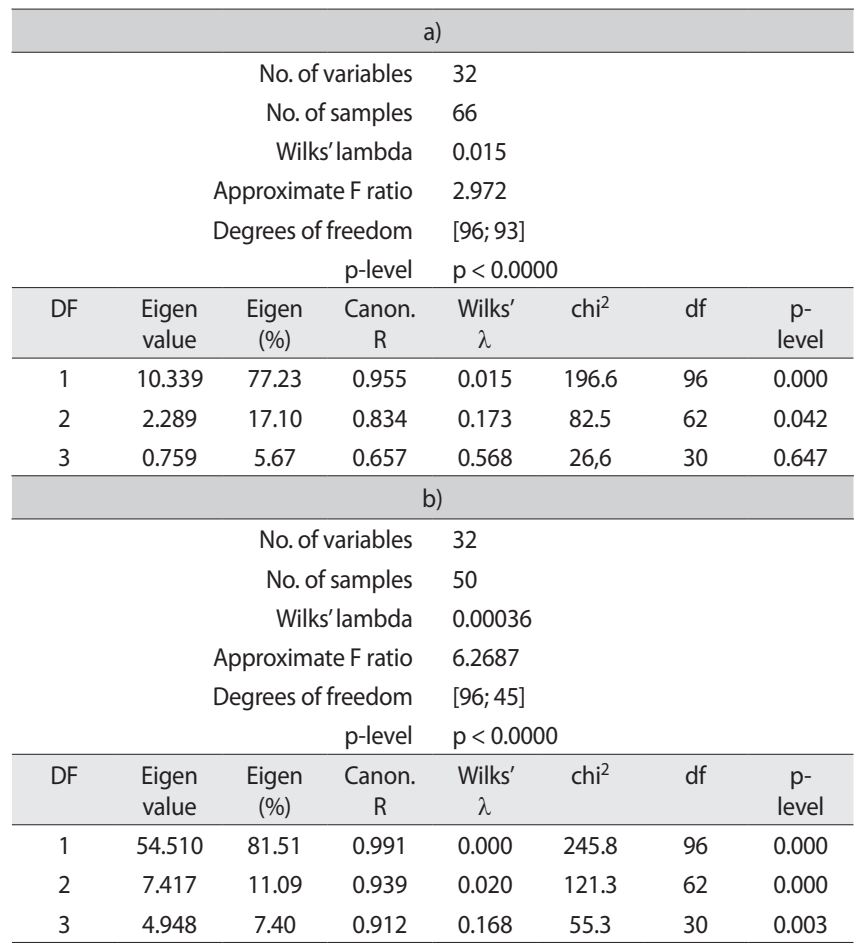

Note: LPB data clr-transformed from KOVAČEVIĆ GALOVIĆ et al., 2012. allowing the third one to be easily disregarded. For the sake of convenience and prevention of possible confusion, the interpretation of the two models will proceed separately allowing, as it were, the LPB model to be ,integrated" with the already built tectonographic scheme of the Istrian Karst (PEH \& KOVAČEVIĆ GALOVIĆ, 2014).

\subsection{Labeling the functions}

The function labeling for the ILPB dataset has been presented in PEH \& KOVAČEVIĆ GALOVIĆ, 2014, so that the pertinent discriminant model of the Istrian karst will only be briefly revisited since the comparison of the two models (ILPB+LPB) is indispensable for their integration into the greater ADCP scheme. It suffices to say that in the computed mathematical model of the ILPB (Tab. 2a; Fig. 5a-b), the first discriminant function DF1 highlights the simple enrichment/depletion master relationship while DF2 provides additional insight both into the process of ferralization experiencing manganese enrichment in the final stages, and into various anaerobic processes affecting organic-rich argillaceous sediments in the poorly drained protobauxitic material. For the LPB model previously constructed by classical statistical techniques all MDA paraphernalia had to be recomputed in the $\mathrm{CoDa}$ spirit (Tab. 2b; Fig. 5c-d).

\subsection{LPB model revisited - the CoDa approach}

Previous investigation of Lower Palaeogene bauxites revealed an exceptional role for $\mathrm{Cr}$ in their disposition over the Dinaric karst (KOVAČEVIĆ GALOVIĆ et al., 2012). However, from the standpoint of statistical modeling, the LPB model discussed in earlier work suffered from a variety of problems arising from the traditional raw data approach. One of the greatest shortcomings was the separate analysis of major and trace elements resulting in two different DFMs, each encumbered by the problem of sub-compositional incoherence (incoherence of the correlation between the two raw components as a measure of dependence) (e.g. PAWLOWSKY-GLAHN \& EGOZCUE, 2006; AITCHISON, 2008). Here, this issue is resolved by the compositional data approach which allows working on the full set of geochemical data in terms of ratios (such as clr coefficients) always preserving sub-compositional coherence. Also, one of the major fallacies related to „classical" statistical methods is exposed by the CoDa analysis. Specifically, in some cases, including the previously established LPB model (KOVAČEVIĆ GALOVIĆ et al., 2012), it may turn out that the new methodology validates what is already known through the use of traditional methods with raw compositional data. However, the straightforward answer to this dilemma is that more often than not ,either the researcher was lucky using his traditional methods or at least the new methodology must be correct in that case" (AITCHISON, 2008).

The CoDa DFM is strikingly similar to its classical counterpart particularly in the portion applying to the group arrangement based on the latter's trace element dataset (KOVAČEVIĆ GALOVIĆ et al., 2012). However, correspondence also exists for the major-element suite so that the new model integrates the whole set of transformed compositional data in Euclidean space allowing for more coherent interpretation of geochemical data in the bauxite-forming environment. This is to say that specific performance of $\mathrm{Cr}$ is reinstated by its complementary positioning with regard to bauxitic/clay components (primarily $\mathrm{K}_{2} \mathrm{O}$, followed by $\mathrm{Al}_{2} \mathrm{O}_{3}, \mathrm{TiO}_{2}$ and others). As a strongly bipolar function, DF1 clearly separates the North Adriatic IST and NAI groups against the Dalmatian NDA and CDA groups (Fig. 5c-d), show- 
Figure 5. Comparison between variables and groups in the ILPB and LPB discriminant function model (clrtransformed data): scatterplots of variable loadings $(a, c)$, and individual objects (samples) (b,d) in reduced discriminant space of the first two discriminant functions (DF1-DF2).
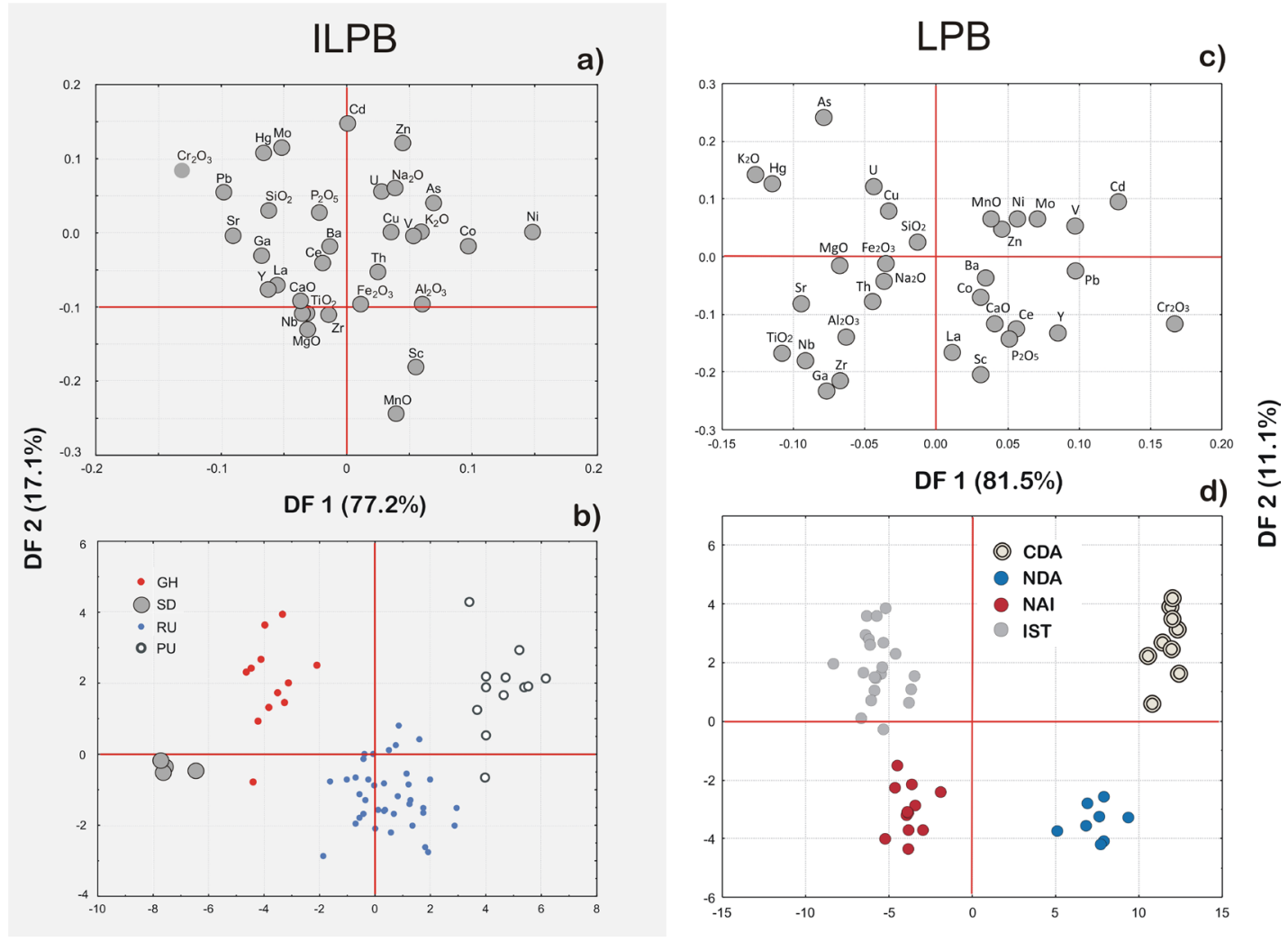

ing the latter as a repository for the ingress of $\mathrm{Cr}$ from some external source - most probably the Dinaridic ophiolite belt with ultramafic massifs and genetically related sedimentary formations (PAMIĆ et al., 2002) in the Internal Dinarides. This input is so strong that, in all probability, the LPB deposited further to the NW simply reflects the sharp decline in Cr content putting to the forefront other bauxite components mentioned above. With the introduction of DF2 (only $11.1 \%$ of total variability) the overall picture is only embellished by separating the NAI and NDA groups as more enriched in aluminum and related components $\left(\mathrm{Al}_{2} \mathrm{O}_{3}, \mathrm{TiO}_{2}, \mathrm{Ga}, \mathrm{Nb}\right)$ as well as rare earths and associated elements $\left(\mathrm{Ce}, \mathrm{La}, \mathrm{P}_{2} \mathrm{O}_{5}, \mathrm{Sc}, \mathrm{Y}\right)$. This leaves the IST group as generally the most kaolinitic $\left(\mathrm{K}_{2} \mathrm{O}\right)$ among the investigated bauxites (upper left quadrant of Fig. 5c-d).

\subsection{A geochemical signal - setting the limits of the bauxite age?}

As suggested before, the specific tectonostratigraphic constraints characterizing different ADCP units imply the possibility of a hidden coherence underlying the unique geochemical signatures of both the ILPB and LPB in general. This particular line of correspondence can be scanned from analogous discriminant models developed for both instances. In this regard the Mahalanobis distances (MD) computed for the ILPB model can be compared with the rebuilt model from the earlier geochemical investigations of the LPB over the entire ADCP (KOVAČEVIĆ GALOVIĆ et al., 2012) as illustrated in Table 3. In the former case the multivariate distances increase successively from the PU upward, putting the $\mathrm{SD}$ at the upper end of the sequence indicating the greatest MD values, more than twice those of the youngest, GH group (Tab. 3a). $\mathrm{RU}$ is also closer, that is, more similar by its geochemical signature, to the GH than to the SD. In the latter however, a somewhat different response is observed, in this instance with regard to the spatial rather than temporal relationships - four LPB groups distributed along the NW-SE directed K-Pg regional unconformity, from Istria (IST) to central Dalmatia (CDA) (spatially ,ascending”, or easting), showed a regular tendency to increase the Cr-signal towards the SE with a characteristic acme at the central Dalmatian (CDA) group, the last in the sequence (IST $\rightarrow$ $\mathrm{NAI} \rightarrow \mathrm{NDA} \rightarrow \mathrm{CDA}$ ) (Tab. 3b).

Hence, spatial and temporal arrows have characteristic peaks that correlate the chronological position of the bauxite-hosting SD formation in Istria (relatable to the supposed $\mathrm{Cr}$-event) with the spatial position of the CDA group of the LPB along the same discontinuity surface at the K-Pg boundary. The rapport between the two models provides a rationale for comparing the controls of subaerial exposure (tectonic uplift in the plate-interior settings during collision along the distant plate margins, according to

Table 3. Mahalanobis distances (MD) for a) ILPB discriminant function model, and b) LPB discriminant function model.

\begin{tabular}{|c|c|c|c|c|c|c|c|c|c|c|c|}
\hline \multirow{2}{*}{$\begin{array}{c}\text { a) } \\
\text { GROUP }\end{array}$} & & \multicolumn{4}{|c|}{ ILPB } & \multirow{2}{*}{$\begin{array}{c}\text { b) } \\
\text { GROUP }\end{array}$} & & \multicolumn{4}{|c|}{ LPB } \\
\hline & & PU & RU & SD & GH & & & IST & NAI & NDA & CDA \\
\hline $\mathrm{GH}$ & & & & & 0.00 & $\mathrm{CDA}$ & & & & & 0.00 \\
\hline SD & 흏 $\frac{0}{\sqrt{n}}$ & & & 0.00 & 31.49 & NDA & $\lesseqgtr$ 山 & & & 0.00 & 83.16 \\
\hline $\mathrm{RU}$ & 윽 & & 0.00 & 70.32 & 28.52 & $\mathrm{NAI}$ & $\Sigma \uparrow$ & & 0.00 & 161.64 & 274.32 \\
\hline PU & & 0.00 & 26.49 & 149.98 & 71.52 & IST & & 0.00 & 40.68 & 202.30 & 309.22 \\
\hline
\end{tabular}

Note: LPB data clr-transformed from KOVAČEVIĆ GALOVIĆ et al., 2012. 
D’ARGENIO \& MINDSZENTY, 1995), invoking an ergodic hypothesis as a working tool. Although some authors hold it inappropriate to swap spatial for temporal variability in ergodic approaches to climate-tectonics-erosion studies (BALCO \& STONE, 2005) it can, in truth, be the only way to model stochastic processes in case if no sample helps meaningfully to predict values that are very far away in time of that sample. This line of reasoning assumes that spatially sampled data can be substituted for time series (PAINE, 1985) which is particularly useful in contrasting the two discussed DFM. A singular, (probably the same) event ( $\mathrm{Cr}$-increase) can be expressed in two models: a) in the temporal model where the ILPB deposited on the SD formation (Upper Cenomanian-Lower Turonian) indicates a specific temporal point during the major hiatus associated with subaerial exposure of the Istrian Karst (ASWu), and; b) in the spatial model where the LPB (IST excluded), are related to a major unconformity between the Uppermost Cretaceous and the Early Palaeogene strata developed under distinctly different tectonostratigraphic constraints prevailing over the High Karst area (DSWu, sensu KORBAR, 2009). In the latter case, the rocks underlying the erosional surface show characteristics of the GH formation originally described on the Island of Brač (GUŠIĆ \& JELASKA, 1990). However, tectonic deformation over the DSWu are more intricate with respect to the Istrian Karst (ASWu), except for the Učka Mt which was strongly affected by the latest orogenic wrench-fault tectonics (PRELOGOVIĆ et al., 1995; PRELOGOVIĆ et al., 2003), representing an area struck by both strike-slip and compressive tectonics (SCISCIANI \& CALAMITA, 2009). In this regard it is worth mentioning that subaerially exposed ILPB deposits are preserved even on the Učka Mt about $800 \mathrm{~m}$ above the Istrian mainland, suggesting that their immediate cover (Middle Eocene foraminiferal limestones; ĆOSOVIĆ et al., 2004) has been stripped off much later prohibiting the complete removal of the ILPB by advancing denudation of the underlying Cretaceous bedrock in spite of the vigorous uplift. This, together with the fact that Brač Island (a model for Upper Cretaceous formations division; GUŠIĆ \& JELASKA, 1990) pertains to the Dalmatian Karst tectonostratigraphic unit (Adriatic NE, or ANEu, sensu KORBAR, 2009) (Fig. 2), showing a somewhat different tectonic pattern, further complicates the clear-cut comparison of the bauxite-hosting lithologic units along the entire $\mathrm{K}-\mathrm{Pg}$ boundary within the ADCP domain. Provided that the $\mathrm{Cr}$-event which filtered through both the ILPB and the LPB was more or less synchronous over the entire karst Dinarides during the K-Pg interval, it would demonstrate different responses of the particular fragments from the Adriatic and Dinaric domains in Croatia to the tectonic deformations caused by the differential spatial influence of the advancing Dinaridic thrust front (KORBAR, 2009; BRLEK et al., 2013).

\subsection{The ILPB model of the Istrian Karst (ASWu)}

As mentioned earlier, results from the previous investigations concerning the bauxites on the Istrian karst (ASWu) (PEH \& KOVAČEVIĆ GALOVIĆ, 2014) ought to be briefly reiterated in order to present the link to the rest of the carbonate platform more clearly. The Istrian Karst seems to be of particular importance since the hiatus in that part of ADCP is associated with a prominent forebulge zone induced by the approaching Dinaridic thrust front, bringing into direct focus the significance of the erosional vacuity. The PU-GH depositional sequences are clearly truncated forming an unconformity which is directly overlain by Eocene foraminiferal limestones and occasionally by the Liburnian formation, (but only in the farthest SE part of the Istrian Peninsula). According to OTONIČAR (2007) the initial uplift of the fore- bulge occurred at the end of the Campanian, which resulted in differential erosion of the subaerially exposed Cretaceous carbonate successions. Controlled by topography, uplift, relief, rate of erosion, vacuity and total stratigraphic gap are all mutually and positively correlated (MINDSZENTY et al., 1995) - the youngest deposits were first to emerge at the crest of a subaerially exposed forebulge and they were also the first to experience erosion. In this process, after complete destruction of the assumed Campanian strata, erosional truncation advanced deeper, affecting the successively older formations. As a result of the migration of the forebulge and the progradation of the associated foreland basin system through time, away from the approaching Dinaric thrust front (in conformity with the model promoted by CRAMPTON \& ALLEN, 1995, and DeCELLES \& GILLES, 1996), both the age of the bedrock immediately underlying the evolved unconformity and the spread of the stratigraphic gap expanded steadily in SW direction (OTONIČAR, 2007). In other words, the K-Pg unconformity in Istria is formed as a „diachronous erosion surface" (sensu YANG, 2011) with the youngest bedrock formation $(\mathrm{GH})$ closer to the orogenic wedge and the older formations successively further away. Naturally, the development of the palaeokarst and the accumulation of the protobauxitic material began with the exhumation of the GH and were brought to an end with the PU, in reverse order with respect to their deposition. With this in mind, the aftermath of the $\mathrm{Cr}$-event as reflected in the DF1 of the ILPB model, can be dated as postCampanian, subsequent to the erosional truncation which cut sufficiently deep to exhume the SD formation. The structure of the DF1 can be attributed to the uplift-related change from phreatic to vadose conditions during karstification of the emerging forebulge similar to that reported by MINDSZENTY et al. (2000) from the Cretaceous of the Transdanubian Range, Hungary. The originally high content of both $\mathrm{Cr}$ and $\mathrm{Ni}$ changes gradually in favour of $\mathrm{Cr}$ due to the loss of $\mathrm{Ni}$ through the process of leaching which intensified towards the crest of the forebulge during uplift. In the incipient stages of evolution of the forebulge the depositional/diagenetic environment probably favoured the settling of phreatic conditions since the newly formed low-level karst planes did not support formation of a deep unsaturated zone with unimpeded drainage. A vadose environment would have been established later when the region of the uplifting forebulge became sufficiently high (generally less than $200 \mathrm{~m}$, according to CRAMPTON \& ALLEN, 1995) to permit free downward circulation of water and the appearance of streams draining the exposed highlands. That period is coeval with exhumation of the SD formation at the crest of the forebulge and subsequent redistribution of the DF1 suite of elements ( $\mathrm{Cr}$ and $\mathrm{Ni}$ in particular) in the proto-bauxite material in accordance with $\mathrm{Eh} / \mathrm{pH}$ conditions controlled by the position of the groundwater table (D'ARGENIO \& MINDSZENTY, 1995). Simultaneously, the diminishing trace element signal in the bauxites towards the PU and RU formations with reemerging significance of Ni relative to $\mathrm{Cr}$ may indicate a decrease in amplitude of the relief and also of the rate of erosion on the distal slope of the forebulge towards the back-bulge basin (SW Istria) (OTONIČAR, 2007) which restored phreatic conditions. Also, the diagenetic environment was likely to change during the early phase of burial, turning the initially vadose conditions into phreatic ones (D'ARGENIO \& MINDSZENTY, 1995). The fact that Cretaceous formations older than Late Albian (PU), extending to the Valanginian, are devoid of ILPB deposits, is indicative of intermittent episodes of subaerial exposure in the Cretaceous. They affected relatively thin carbonate successions in SW Istria due to recurrent brief emersions during the Early Cre- 
taceous (MATIČEC et al., 1996), which prevented the formation of bauxite deposits.

It is obvious that the $\mathrm{Cr}-\mathrm{Ni}$ polarity relationship described above represents the keynote striking the answering chord in the whole set of processes related to bauxitization in the forebulge zone during its development. In this regard, another set of geochemical processes defined by the DF2 may elucidate the progressive changes and maturation of the proto-bauxitic material during the movement of the forebulge and the progressive formation of the unconformity. It is functional within the same matrix of tectonostratigraphic constraints explained by the DF1, exhibiting, however, a slight shift in time. Due to the reducing environment established in the early stages of the forebulge uplift (swampy lowlands across the emerged GH formation), the process of lateritization (ferralitization) of the proto-bauxitic material could not have progressed very far while chalcophile elements were coprecipitated with Fe-sulfides or, as suggested from Fig. 5a-b ( $\mathrm{Fe}_{2} \mathrm{O}_{3}$ opposing chalcophiles), occurring in the form of discrete metal sulfide phases (KORETSKY et al., 2006), with both potentially being adsorbed on clay minerals. Following exhumation of the SD formation, vadose conditions were established, which reinforced the process of karstification and chemical reworking of the proto-bauxite. However, only with the emergence of the RU formation did the protobauxitic material achieve its full maturity with the removal of all mobile elements (Ni was removed earlier during the SD phase) and accumulation of Al, Fe, and Mn oxyhydroxides. Finally, due to flexural subsidence in the distal parts of the forebulge, similar conditions were restored in regard to the PU formation. It was characterized by the reinstatement of the reducing environment, accommodating the same suite of components as in the initial stage of the uplift (Fig. 5a-b).

\subsection{Integrating the models into the broader tectonostratigraphic scheme}

Subaerial exposure of the Istrian part of the ASWu and associated bauxitization probably lasted until the Early Eocene when platform conditions were restored burying the previously formed unconformity under foraminiferal limestones (ĆOSOVIĆ et al., 2004). A similar forebulge effect in approximately the same period was also hypothesized in the central part of the High Karst (DSWu) where the underlying carbonate bedrock mostly refers to the GH formation (Coniacian to Santonian) (KORBAR, 2009). However, in this area the discontinuity surface may not exhibit clear diachronism which in Istria is plainly indicated by the contrasting position of $\mathrm{Cr}$ and $\mathrm{Ni}$ in the bauxite geochemical signature. In this sense the LPB lithofacies in a spatially confined geotectonic setting of the External Dinarides (NAI-CDA groups) cannot be squarely associated with a specific age interval between emersion and final drowning of both the ASWu and DSWu. It is particularly evident in the case of LPB groups outside Istria where bauxite deposits are regularly ,sandwiched" between Santonian (Early Campanian) footwall and Early Eocene hanging wall carbonate rocks betraying the apparent synchronicity along the entire K-Pg boundary in this part of the investigated area. The proposed models demonstrate that the prominent position of the SD bauxites in Istria is brought about by the bulging effect manifested in the inverse $\mathrm{Cr} / \mathrm{Ni}$ relationship (Fig. 5a-b) in a fashion previously described. However, a similar $\mathrm{Cr} / \mathrm{Ni}$ status is missing in the LPB model where Ni stands relatively close to $\mathrm{Cr}$ (positive association) for both Dalmatian groups (NDA and CDA) (Fig. 5c-d) indicating the absence of apparent bulging in the NE part of the DSWu. In all probability, the close $\mathrm{Cr} / \mathrm{Ni}$ relationship in the easternmost portion of the DSWu has been developed as a net feedback from slow uplift prohibiting effective draining and elimination of phreatic conditions which resulted in the distinctly gibbsitic character of the CDA proto-bauxite material during the entire emergent stage (KOVAČEVIĆ GALOVIĆ et al., 2012). Both rich in Cr, the aforementioned groups are, nonetheless, not quite close together with regard to their general geochemical signal, as is clearly demonstrated by Mahalanobis distances (MD) calculated for both models. MD values locate the CDA group to the far end of the LPB spatial sequence (Tab. 3) while the SD group is placed somewhere in the „middle" of the ILPB temporal succession. Model comparisons based on MD values demonstrate that both prominent groups (SD and CDA) are located farthest from their respective ,reference points”, that is, the PU and IST groups, suggesting thereby the period of most intense Cr-enrichment as the correlating event. When established, the general statistical reciprocity between the two bauxite lithofacies reveals (in light of the ergodic assumption), the space-time symmetry in the process of the profound geochemical change and reworking of the initial geochemical signal (input of $\mathrm{Cr} / \mathrm{Ni}$-rich material) across the entire ADCP, that is, both its Adriatic and Dinaric domains (cf. Fig. 5). It implies that the SD is closest in time while the CDA is closest in space to the supposed Cr-event (input of source material). However, it is essential that the supposed event cannot be decoupled from geochemical processes affecting the $\mathrm{Cr} / \mathrm{Ni}$ partition in protobauxites during subaerial exposure of the karst environment. This means that the major contrast between the bauxite lithofacies from two ADCP domains, exposed through divergent geochemical fates of the two dominant element pair, is defined primarily by the presence/absence of the forebulge dynamics and ensuing environmental control over the carbonate platform. Last but not least, the geochemical signature of both bauxite domains (ILPB and LPB), as communicated through the all-important DF1 in both CoDa DFMs, most probably indicates the temporal inequality between the duration of subaerial exposure of Istrian GH and its High Karst platform-interior counterpart.

\section{CONCLUSION}

The origin and emplacement of Lower Palaeogene bauxites on the Adriatic-Dinaric carbonate platform was explored in light of the recent advancements in the modeling of the foreland basin systems. In the Istrian part of the platform (ASWu) bauxitization was coeval with expansion of the collision-induced diachronous discontinuity surface, a process assumed to have been developed under strong tectonic control (uplift of a flexural bulge) during the initial stages of orogeny. To this purpose, a discriminant function model of the ILPB compositional data (whole rock geochemical data) was constructed beforehand, providing the solid ground for the separation of bauxite samples (based on lithostratigraphic units or formations) derived from the developing subaerial exposure of the Istrian Cretaceous/Palaeogene palaeoenvironment. Attention was then paid towards finding distinctive geochemical signatures in the bauxites (LPB) from the neighbouring tectonostratigraphic unit (DSWu) in order to recognize the possible development of forebulge unconformities elsewhere across the platform. A similar model of the entire ADCP (based on geographical deployment of the bauxite groups) was adopted from earlier investigations and restructured after the principles of compositional data analysis, in order to assess the geochemical correspondence between the two event-markers (ILPB and LPB) at the same regional unconformity. The need for clarification of the nature of tectonostratigraphic constraints, especially those involved in forebulge dynamics, has occurred as a logical net effect associated 
with the proposed modeling of the bauxite lithofacies in terms of the spatial/temporal relationships.

The most important results of these investigations can be summarized as follows:

a) Both models heavily rely on the importance of the first discriminant function which comprises 77.2 and $81.5 \%$ of the total variability in the ILPB and LPB models, respectively, albeit with different implications in terms of geochemical processes. In the ILPB model DF1, it is interpreted as reflecting the intricate environmentally-controlled $\mathrm{Ni} / \mathrm{Cr}$ enrichment-depletion relationship whereas in the DF2 it is a supplementary process (17.1\%) explained as manifesting the interchange between vadose and phreatic bauxite-forming environments due to changing redox conditions. Both functions, however, appeal to the effects of intraplatform tectonic activity with the purpose of clarifying the specified geochemical controls. In the LPB model DF1 the specific performance of $\mathrm{Cr}$ is established by its complementary positioning with regards to bauxitic/clay components (primarily $\mathrm{K}_{2} \mathrm{O}$ ) while the DF2 (11.1\%) reflects enrichment (or reduction) in $\mathrm{Al}_{2} \mathrm{O}_{3}$ and related components typical for bauxites.

b) The discontinuity surface underlying the ILPB is characterized by diachronism caused by the development of a flexural forebulge on the Istrian part of the ASWu. Forebulge evolution is recorded in the ILPB geochemical signature by assigning to the $\mathrm{SD}$ bauxite group a pivotal position in the significant geochemical $(\mathrm{Cr} / \mathrm{Ni})$ partitioning after the initial input of source material. Bauxite-hosting SD and RU formations mark the maximum possible cumulative uplift and erosion, facilitating maturation of the proto-bauxitic material under oxidizing, vadose conditions. In contrast, the PU group, formed on the distal flank of the forebulge (away from the orogenic wedge), shows evidence of the geochemical signal characteristic of reducing conditions. In the case of the LPB, the North Adriatic IST and NAI groups are clearly separated from the Dalmatian NDA and CDA groups in such a manner that the latter participate as a repository for the chromium ingress from some extraneous source - most probably the Dinari= dic ophiolite belt).

c) Comparison of the ILPB and LPB models via an ergodic approach brings into the foreground the pivotal status of the SD $(\mathrm{ASWu})$ and CDA (DSWu) bauxite groups dictated by existing ADCP tectonostratigraphic constraints. In light of a supposed $\mathrm{Cr}$-event it indicates both divergent geochemical fates of the most important descriptor variables ( $\mathrm{Cr}$ and $\mathrm{Ni}$ ) with respect to development of a flexural bulge, and the temporal inequality of the Istrian $\mathrm{GH}$ formation (ASWu) and its High Karst counterpart (DSWu).

\section{ACKNOWLEDGMENT}

This study was supported by The Ministry of Science, Education and Sports, Republic of Croatia (MZOS) via the former Scientific Project (zProject): The Geological Maps of the Republic of Croatia. Their support is greatly appreciated. The authors wish to express their gratitude to the reviewers for their thoughtful suggestions and comments. Thanks are also due to all who have contributed to the execution of this research.

\section{REFERENCES}

AITCHISON, J. (1982): The statistical analysis of compositional data (with discussion).J. Roy. Stat. Soc. Series B, 44, 139-177.

AITCHISON, J. (1986): The Statistical Analysis of Compositional Data.- Chapman and Hall, London-New York, 416 p. doi:10.1002/bimj.4710300705

AITCHISON, J. (2008): The single principle of compositional data analysis, continuing fallacies, confusions and misunderstandings and some suggested remedies.- In:
DAUNIS-i-ESTADELLA, J. \& MARTÍN-FERNÁNDEZ, J.A. (eds.): Proceedings of CoDaWork'08, the $3^{\text {rd }}$ Compositional Data Analysis Workshop, May 27-30, University of Girona, Girona (Spain), 1-28.

AITCHISON, J. \& EGOZCUE, J.J. (2005): Compositional data analysis: where are we and where should we be heading?-Math. Geol., 37, 829-850. doi:10.1007/s11004005-7383-7

ANALYTICAL METHODS COMMITTEE (1987): Recommendations for the definition, estimation and use of the detection limit.-Analyst, 112, 199-204. doi:10.1039/ AN9871200199

ANTWEILER, R.C. \& TAYLOR, H.E. (2008): Evaluation of statistical treatments of left-censored environmental data using coincident uncensored data sets: I. Summary statistics.- Environ. Sci. Technol., 42, 3732-3738. doi:10.1021/es071301c.

BALCO, G. \& STONE, O.H.J. (2005): Measuring Pleistocene erosion rates with cosmogenic nuclides in buried alluvial sediment, Fisher Valley, southeastern Utah.Earth Surf. Proc. Land., 30, 1051-1067. doi: 10.1002/esp.1262.

BARCELÓ-VIDAL, C., \& PAWLOWSKY-GLAHN, V. (1999): Letter to the Editor: Comment on ,Singularity and Nonnormality in the Classification of Compositional Data“ by BOHLING, G.C., DAVIS, J.C., OLEA, R.A. \& HARFF, J.- Math. Geol., 31, 581-585.

BLAŠKOVIĆ, I., DRAGIČEVIĆ, I. \& POKRAJČIĆ, I. (1989): Tectonic control of the origin of the paleorelief of bauxite deposits in the Western Herzegovina, Yugoslavia.- Travaux ICSOBA, 19/22, 231-238.

BRLEK, M., KORBAR, T., CVETKO TEŠOVIĆ, B., GLUMAC, B. \& FUČEK, L. (2013): Stratigraphic framework, discontinuity surfaces and regional significance of Campanian slope to ramp carbonates from central Dalmatia, Croatia.- Facies, 59, 779-801. doi: 10.1007/s10347-012-0342-0

BRLEK, M., KORBAR, T., KOŠIR, A., GLUMAC, B., GRIZELJ, A. \& OTONIČAR, B. (2014): Discontinuity surfaces in Upper Cretaceous to Paleogene carbonates of central Dalmatia (Croatia): Glossifungites ichnofacies, biogenic calcretes, and stratigraphic implications.-Facies, 60, 467-487. doi:10.1007/s10347-013-0378-9.

BUCCIANTI, A. (2013): Is compositional data analysis a way to see beyond the illusion?-Comp. Geosci., 50, 165-173. doi:10.1016/j.cageo.2012.06.012.

BUCCIANTI, A., MATEU-FIGUERAS, G. \& PAWLOWSKY-GLAHN, V. (eds.) (2006): Compositional Data Analysis in the Geosciences: From Theory to Practice.- Geol. Soc. Spec. Publ., The Geological Society London, 264, 224 p.

CRAMPTON, S.L. \& ALLEN, P.A. (1995): Recognition of forebulge unconformities associated with early stage foreland basin development; example from the North Alpine foreland basin.-AAPG Bull., 79, 1495-1514.

CVETKO TEŠOVIĆ. B., GUŠIĆ, I., JELASKA, V. \& BUCKOVIĆ, D. (2001): Stratigraphy and microfacies of the Upper Cretaceous Pućišća Formation, Island of Brač, Croatia. Cretaceous Res., 22, 591-613. doi: 10.1006/cres.2001.0279.

CVETKO TEŠOVIĆ, B., GLUMAC, B. \& BUCKOVIĆ, D. (2011): Integrated biostratigraphy and carbon isotope stratigraphy of the Lower Cretaceous (Barremian to Albian) Adriatic-Dinaridic carbonate platform deposits in Istria, Croatia.- Cretaceous Res., 32, 301-324. doi:10.1016/j.cretres.2010.12.011.

ĆOSOVIĆ, V., DROBNE, K. \& MORO, A. (2004): Paleoenvironmental model for Eocene foraminiferal limestones of the Adriatic carbonate platform (Istrian Peninsula).- Facies, 50, 61-75. doi:10.1007/s10347-004-0006-9.

D'ARGENIO, B. \& MINDSZENTY, A. (1995): Bauxites and related palaeokarst: tectonic and climatic event markers at regional unconformities.-Eclogae Geol. Helv., $88,453-499$.

DAUNIS-i-ESTADELLA, J., THIÓ-HENESTROSA, S. \& MATEU-FIGUERAS, G. (2011): Two more things about compositional biplots: quality of projection and inclusion of supplementary elements.- In: EGOZCUE, J.J., TOLOSANA-DELGADO, R. \& ORTEGO, M.I. (eds.): Proceedings of the $4^{\text {th }}$ International Workshop on Compositional Data Analysis (CoDaWork'11), Girona, 1-14.

DeCELLES, P.G. \& GILES, K.A. (1996): Foreland basin systems.- Basin Res., 8, 105 123.

DURN, G., OTTNER, F., TIŠLJAR, J., MINDSZENTY, A. \& BARUDŽIJA, U (2003): Regional Subaerial Unconformities in Shallow-Marine Carbonate Sequences of Istria: Sedimentology, Mineralogy, Geochemistry and Micromorphoplogy of Associated Bauxites, Paleosols and Pedo-Sedimentary Complexes. Field Trip P8, 209-254.- In: VLAHOVIĆ, I. \& TIŠLJAR, J. (eds): Field Trip Guidebook of 22nd IAS Meeting of Sedimentology, Opatija, $256 \mathrm{p}$.

EGOZCUE, J.J. \& PAWLOWSKY-GLAHN, V. (2006): Simplicial geometry for compositional data.- In: BUCCIANTI, A., MATEU-FIGUERAS, G. \& PAWLOWSKY-GLAHN, V. (eds): Compositional Data Analysis in the Geosciences: From Theory to Practice. London: Geol. Soc. Spec. Publ., 264, 145-158.

GALOVIĆ, L. \& PEH, Z. (2016): Mineralogical discrimination of the pleistocene loess/ paleosol sections in Srijem and Baranja, Croatia.- Aeolian Res., in press. doi: 10.1016/j.aeolia.2016.04.006

GUŠIĆ, I. \& JELASKA, V. (1990): Stratigrafija gornjokrednih naslaga otoka Brača u okviru geodinamske evolucije Jadranske karbonatne platforme (Upper Cretaceous stratigraphy of the Island of Brač within the geodynamic evolution of the Adriatic carbonate platform).- Djela Jugoslavenske akademije znanosti i umjetnosti, 69, Institut za geološka istraživanja, Zagreb, 160 p. 
HINSBERGEN, D.J.J., MENSINK, M., LANGEREIS, C.G., MAFFIONE, M., SPALLUTO, L., TROPEANO, M. \& SABATO, L. (2014): Did Adria rotate relative to Africa?- Solid Earth, 5, 611-629. doi:10.5194/se-5-611-2014

HRVATSKI GEOLOŠKI INSTITUT (CROATIAN GEOLOGICAL SURVEY) (2009): Geološka karta Republike Hrvatske 1:300000 (Geological Map of the Republic of Croatia 1:300000), Zagreb.

KORBAR, T. (2009): Orogenic evolution of the external Dinarides in the NE Adriatic region; a model constrained by tectonostratigraphy of Upper Cretaceous to Paleogene carbonates.-Earth-Sci. Rev., 96, 296-312. doi: 10.1016/j.earscirev.2009.07.004.

KORBAR, T., GLUMAC, B., CVETKO TEŠOVIĆ, B. \& CADIEUX, S.B. (2012): Response of a Carbonate Platform to the Cenomanian-Turonian Drowning and OAE 2: a Case Study from the Adriatic Platform (Dalmatia, Croatia).- J. Sediment. Res., 82, 163-176. doi: 10.2110/jsr.2012/17

KORETSKY, C.M., HAAS, J.R., MILLER, D, \& NDENGA, N.T. (2006): Seasonal variations in pore water and sediment geochemistry of littoral lake sediments (Asylum Lake, MI, USA).- Geochemical T., 7/11, 1-26. doi:10.1186/1467-4866-7-11

KOVAČEVIĆ GALOVIĆ, E., ILIJANIĆ, N., PEH, Z., MIKO, S. \& HASAN, O. (2012): Geochemical discrimination of Early Palaeogene bauxites in Croatia.- Geol. Croat, 65, 53-65. doi: 104154/gc.2012.04

MÁRTON, E., DROBNE, K., ĆOSOVIĆ, V. \& MORO, A. (2003): Palaeomagnetic evidence for Tertiary counterclockwise rotation of Adria.- Tectonophysics, 377, 143-156. doi:10.1016/j.tecto.2003.08.022

MÁRTON, E., ZAMPIERI, D., GRANDESSO, P., ĆOSOVIĆ, V. \& MORO, A. (2010): New Cretaceous paleomagnetic results from the foreland of the Southern Alps and the refined apparent polar wander path for stable Adria.- Tectonophysics, 480, 57-72. doi:10.1016/j.tecto.2009.09.003

MÁRTON, E., ZAMPIERI, D., KÁZMÉR, M., DUNKL, I. \& FRISCH, W. (2011): New Paleocene-Eocene paleomagnetic results from the foreland of the Southern Alps confirm decoupling of stable Adria from the African plate.- Tectonophysics, 504, 89-99. doi:10.1016/j.tecto.2011.03.006.

MATIČEC, D. (1994): Neotectonic deformations in Western Istria, Croatia.- Geol. Croat., 47/2, 199-204.

MATIČEC, D., VLAHOVIĆ, I., VELIĆ, I. \& TIŠLJAR, J. (1996): Eocene limestones overlying Lower Cretaceous deposits of western Istria (Croatia): did some parts of present Istria form land during the Cretaceous?- Geol. Croat., 49, 117-127.

MATIČEC, D., FUČEK, L., PALENIK, D. \& OŠTRIĆ, N. (2013): Geological setting of the Istrian County.- In: MIKO, S., KRUK, B., DEDIĆ, Ž., KRUK, Lj., PEH, Z., KOVAČEVIĆ GALOVIĆ, E. \& GABRIĆ, A. (eds.): Mining-Geological Study of Potentiality and Mineral Resources Management in the Area of Istrian County.Croatian Geological Survey, Zagreb, Croatia, 19-48. (In Croatian).

MINDSZENTY, A., D'ARGENIO, B. \& AIELLO, G. (1995): Lithospheric bulges recorded by regional unconformities. The case of Mesozoic - Tertiaty Apulia.- Tectonophysics, 252, 137-161.

MINDSZENTY, A., CSOMA, A., TÖRÖK, Á., HIPS, K. \& HERTELENDI, E. (2000): Flexura jellegű előtéri deformációhoz köthető karsztbauxitszintek a Dunántúliközéphegységben (Rudistid limestones, bauxites, paleokarst and geodynamics. The case of the Cretaceous of the Transdanubian Range).- Bull. Geol. Soc. Hung., 131/1-2, 107-152 (in Hungarian with ext. English abstract).

NOCQUET, J.-M. (2012): Present-day kinematics of the Mediterranean: A comprehensive overview of GPS results.- Tectonophysics, 579, 220-242. doi: 10.1016/j. tecto.2012.03.037.

OTONIČAR, B. (2007): Upper Cretaceous to Paleogene forbulge unconformity associated with foreland basin evolution (Kras, Matarsko podolje and Istria; SW Slovenia and NW Croatia).- Acta Carsologica, 36/1, 101-120.

OTONIČAR, B. (2008): Evolution of paleokarst related to a forebulge unconformity; an example from the late Cretaceous and Paleogene of Kras, Matarsko Podolje and Istria, southwest Slovenia and northwest Croatia.- In: SASOWSKY, I.D., FEAZEL, C.T., MYLROIE, J.E., PALMER, A.N. \& PALMER, M.V (eds): Karst from Recent to Reservoirs, Karst Waters Institute Special Publication 14, Leesburg, Virginia, $221 \mathrm{p}$.

PAINE, A.D.M. (1985): 'Ergodic' reasoning in geomorphology: time for a review of the term? - Prog. Phys. Geog., 9, 1-15. doi: 10.1177/030913338500900101

PAMIĆ, J, BALEN, D. \& HERAK, M. (2002): Origin and geodynamic evolution of Late Paleogene magmatic associations along the Periadriatic-Sava-Vardar magmatic belt.- Geodin. Acta, 15, 209-231.

PAWLOWSKY-GLAHN, V. \& EGOZCUE, J.J. (2006): Compositional data and their analysis: an introduction.- In: BUCCIANTI A, MATEU-FIGUERAS, G. \& PAWLOWSKY-GLAHN, V. (eds): Compositional Data Analysis in the Geosciences: From Theory to Practice. Geol. Soc. Spec. Publ., 264, 1-10. DOI: 10.1144/GSL. SP.2006.264.01.01

PEH, Z. \& HALAMIĆ, J. (2010): Discriminant function model as a tool for classification of stratigraphically undefined radiolarian cherts in ophiolite zones.- Journal. Geochem. Explor., 107, 30-38. DOI: 10.1016/j.gexplo.2010.06.003.

PEH, Z. \& KOVAČEVIĆ GALOVIĆ, E. (2014): Geochemistry of Istrian Lower Palaeogene bauxites - Is it relevant to the extent of subaerial exposure during Cretaceous times?- Ore Geol Rev., 63, 296-306.
PRELOGOVIĆ, E., KUK, V., JAMIČIĆ, D., ALJINOVIĆ, B. \& MARIĆ, K. (1995): Seizmotectonic activity of the Kvarner area (in Croatian).- In: VLAHOVIĆ, I., VELIĆ, I. \& ŠPARICA, M. (eds.): Proceedings of the First Croatian Geological Congress, Vol. 2., Croatian Geological Society and Institute of Geology, Zagreb, 487-490.

PRELOGOVIĆ, E., PRIBIČEVIĆ, B., IVKOVIĆ, Ž., DRAGIČEVIĆ, I., BULJAN, R. $\&$ TOMLJENOVIĆ, B. (2003): Recent structural fabric of the Dinarides and tectonically active zones important for petroleum-geological exploration in Croatia.Nafta, $55,155-161$

REIMANN, C., FILZMOSER, P., FABIAN, K., HRON, K., BIRKE, M., DEMETRIADES, A., DINELLI, E. \& LADENBERGER, A. \& The GEMAS Project Team (2012): The concept of compositional data analysis in practice - Total major element concentrations in agricultural and grazing land soils of Europe.- Sci Total. Environ., 426, 196-210. doi: 10.1016/j.scitotenv.2012.02.032.

SAKAČ, K. \& ŠINKOVEC, B. (1991): The Bauxites of the Dinarides. Travaux ICSOBA, 20-21, 1-11.

SCHMID, S. M., BERNOULLI, D., FÜGENSCHUH, B., MATENCO, L., SCHEFER, S., SCHUSTER, R., TISCHLER, M. \& USTASZEWSKI, K. (2008): The AlpineCarpathian-Dinaridic orogenic system: correlation and evolution of tectonic units.Swiss J Geosci, 101, 139-183.

SCISCIANI, V. \& CALAMITA, F. (2009): Active intraplate deformation within Adria: Examples from the Adriatic region.- Tectonophysics, 476, 57-72. doi: 10.1016/j. tecto.2008.10.030.

StatSoft, Inc. (2006): STATISTICA (Data Analysis Software System), Releaase 7.1; www.statsoft.com2006

STEUBER, T., KORBAR, T., JELASKA, V. \& GUŠIĆ, I. (2005): Strontium-isotope stratigraphy of Upper Cretaceous platform carbonates of the island of Brač (Adriatic Sea, Croatia): implications for global correlation of platform evolution and biostratigraphy.- Cretaceous Res., 26/5, 741-756.

ŠINKOVEC, B. (1973): The origin of Early Palaeogene bauxites of Istria, Yugoslavia.Travaux ICSOBA, 3, 151-164

ŠINKOVEC, B. \& SAKAČ, K. (1982): The Paleogene bauxites of Dalmatia.- Travaux ICSOBA, 12, 293-331.

ŠINKOVEC, B. \& SAKAČ, K. (1991): Bauxite deposits of Yugoslavia - the state of the Art.- Acta Geol. Hung., 34/4, 307-315.

ŠUMANOVAC, F. (2010): Lithosphere structure at the contact of the Adriatic microplate and the Pannonian segment based on the gravity modelling.- Tectonophysics, 485, 94-106. doi:10.1016/j.tecto.2009.12.005

TARVAINEN, T., REEDER, S. \& ALBANESE, S. (2005): Database management and map production.- In: SALMINEN, R., BATISTA, M.J., BIDOVEC, M., DEMETRIADES, A., De VIVO, B., De VOS, W., DURIS, M., GILUCIS, A., GREGORAUSKIENE, V., HALAMIĆ, J., HEITZMANN, P., JORDAN, G., KLAVER, G., KLEIN, P., LIS, J., LOCUTURA, J., MARSINA, K., MAZREKU, A., O'CONNOR, P.J., OLSSON, S.Å., OTTESEN, R.-T., PETERSELL, V., PLANT, J,A,, REEDER, S,, SALPETEUR, I,, SANDSTRÖM, H., SIEWERS, U., STEENFELT, A. \& TARVAINEN, T. (eds): Geochemical Atlas of Europe, Part 1, Background Information, Methodology and Maps. Espoo: Geological Survey of Finland, $1-4$.

TIŠLJAR, J., VLAHOVIĆ, I., VELIĆ, I., MATIČEC, D. \& ROBSON, J. (1998): Carbonate facies evolution from the Late Albian to Middle Cenomanian in southern Istria (Croatia): influence of synsedimentary tectonics and extensive organic carbonate production.- Facies, 38, 37-151.

TOLOSANA-DELGADO, R., OTERO, N. \& PAWLOWSKY-GLAHN, V. (2005): Some Basic Concepts of Compositional Geometry.- Math. Geol., 37, 673-680. doi: 10.1007/s11004-005-7374-8.

TOLOSANA-DELGADO, R. (2012): Uses and misuses of compositional data in sedimentology.- Sediment. Geol., 280, 60-79. doi: 10.1016/j.sedgeo.2012.05.005.

USTASZEWSKI, K., KOUNOV, A., SCHMID, S.M., SCHALTEGGER, U., KRENN, E., FRANK, W. \& FÜGENSCHUH, B. (2010): Evolution of the Adria-Europe plate boundary in the northern Dinarides: From continent-continent collision to back-arc extension, Tectonics, 29, TC6017. doi:10.1029/2010TC002668

VELIĆ, I., TIŠLJAR, J., MATIČEC, D. \& VLAHOVIĆ, I. (1995): A review of the Geology of Istria.- In: VLAHOVIĆ, I. \& VELIĆ, I. (eds): Excursion Guidebook, First Croatian Geological Congress, Croatian Geological Society and Institute of Geology, 21-30.

VLAHOVIĆ, I. (1999): Carbonate facies of shallow water depositional systems from Kimmeridgian to Late Albian in western Istria:- Unpubl. $\mathrm{PhD}$ thesis (in Croatian with English summary).- University of Zagreb, $327 \mathrm{p}$.

VLAHOVIĆ, I., TIŠLJAR, J., VELIĆ, I. \& MATIČEC, D. (2005): Evolution of the Adriatic carbonate platform: palaeogeography, main events and depositional dynamics.- Palaeogeogr. Palaeocl., 220, 333-360. doi: 10.1016/j.palaeo.2005.01.011.

YANG, Y. (2011): Tectonically-driven underfilled-overfilled cycles, the middle Cretaceous in the northern Cordilleran foreland basin.- Sediment. Geol., 233, 15-27. doi: 10.1016/j.sedgeo.2010.10.002. 